\title{
Penggunaan Bentuk Sapaan Julukan oleh Masyarakat Desa Rumoong-Lansot
}

Boy Lumoindong

Boy_77lumoindong@gmail.com

Golda J. Tulung

Christian G. Ranuntu

Pascasarjana Unsrat

\begin{abstract}
Abstrak
Nicknaming and its uses in daily communication by the people of RumoongLansot villages are considered as both social and lingual phenomena that have existed since a very long time ago and unconsciously have become the internal part of daily interaction of the people. A well-maintained relationship among the individuals in the society is one of the major factors that endorsed them to address each other by using proper nicknames. No matter old or young people, male or female, wealthy or destitute, indigenous or non indigenous, are all unexceptional unrestrained for nicknaming and employing nicknames between one another.

The results of this research showed that term of nicknames employed by the people of Rumoong-Lansot villages concealed nearly the entire elements of internal linguistics and external linguistics. In term of types, all those nicknames that have been successfully collected and analyzed can be categorized into the following aspects: physical state, home and place of birth, occupation, particular moment, and every other feature that promotes the creation of the nicknames. Generally speaking, every single nickname employed by the people is conditioned to identify one specific member of the society in order to generate a clear and unimpeded sort of communication. Specifically, every single nickname is responsible to provide a distinguished portrayal of any peculiar individual in the society, and even more definite, about his most dominating distinctive characteristics.
\end{abstract}

\section{Pendahuluan}

Peran bahasa sangat mendasar dalam membangun komunikasi yang utuh, jernih dan tidak terhalang dalam masyarakat serta menjadi kunci penentu menuju keberhasilan komunikasi antar anggota masyarakat. Seperti yang ditegaskan oleh Kridalaksana (2008: 24) "Bahasa adalah bunyi yang dipergunakan oleh masyarakat untuk bekerjasama, berinteraksi, dan mengidentifikasi diri”. Menurut Fishman (1971:17), bahasa tidak hanya digunakan untuk menjelaskan segala sesuatu tetapi juga sebagai alat untuk mengekspresikan identitas dan hubungan sosial. Mengenai pemakaian bahasa 
oleh masyarakat, Halliday dalam Mahsun, (2007:206) mengelompokkannya kedalam 3 (tiga) dimensi yaitu: bidang (field), berhubungan dengan mengapa bahasa itu digunakan; cara (mode), berhubungan dengan media apa yang digunakan dalam suatu peristiwa berbahasa, misalnya lisan atau tulisan; dan tenor yang mengacu pada hubungan peran antara para partisipan yang terlibat dalam proses berbahasa. Hubungan peran ini menentukan tingkat keresmian bahasa yang digunakan oleh para partisipan dan dapat dipandang menentukan tingkat keresmian situasinya. Kondisi ini akhirnya menentukan derajat keresmian bahasa yang digunakan dalam situasi tertentu. Dengan demikian tenor dipandang merujuk pada ragam-ragam bahasa menurut keresmiannya, yang dalam bahasa Inggris diketahui memiliki 5 \{lima\} ragam resminya, yaitu beku (frozen), resmi (formal), konsultative (consultative), santai (casual), dan akrab (intimate).

Dari kelima ragam bahasa di atas, dua diantaranya merupakan ragam bahasa yang paling banyak digunakan oleh masyarakat luas. Hal ini disebabkan karena komunikasi masyarakat sehari-hari lebih banyak terlibat dalam situasi santai (casual) dan akrab (intimate) jika dibandingkan dengan dengan situasi beku (frozen), resmi (formal), dan konsultatif (consultative). Ditengah komunikasi yang santai dan akrab, masyarakat biasanya tidak menggunakan bahasa formal karena penggunanaan bahasa formal cenderung membatasi keakraban hubungan antar satu individu dengan individu lain. Pilihan kata yang digunakan masyarakat dalam komunikasi sehari-hari biasanya sederhana bahkan sering muncul istilah-istilah yang memperlihatkan tingkat kedekatan antara mereka yang terlibat dalam komunikasi itu. Bagi orang-orang yang tidak mengetahui tingkat keakraban mereka, istilah-istilah yang digunakan kadang terasa asing dan janggal di telinga namun tidak demikian bagi para penggunanya. Hal itu disebabkan karena tingkat kedekatan hubungan mereka yang begitu tinggi sehingga penggunaan istilah-istilah yang oleh orang lain terasa asing namun oleh mereka dipandang sebagai sesuatu yang biasa. Salah satu ciri penggunaan istilah dalam komunikasi masyarakat yang santai dan akrab yaitu dengan digunakannya julukan (nickname).

Starks and Leech (2015) "A Research Project on Nicknames and Adolescent Identities" menjelaskan bahwa dalam berbagai praktek pemberian nama, orang yang diberikan nama tidak memiliki atau hanya memiliki sedikit kendali atas nama tersebut. 
Nama julukan diberikan dan berlaku seumur hidup sehingga memungkinkan seseorang untuk diidentifikasi dengan nama itu. Hampir semua nama julukan berhubungan dengan sifat-sifat khas yang menonjol pada seseorang. Nama samaran cenderung berhubungan dengan karakteristik fisik seperti berat badan, tinggi, warna, kebiasaan dan sifat pribadi.

Di desa Rumoong Atas dan desa Lansot (dua desa yang berbeda secara administrasi namun satu secara geografis di Kabupaten Minahasa Selatan, selanjutnya disebut desa Rumoong-Lansot), seperti halnya desa lain di sekitarnya, masyarakat menggunakan bahasa Melayu Manado sebagai alat komunikasi mereka sehari-hari. Di kedua desa ini, penduduk saling menyapa satu dengan yang lainnya dengan memperhatikan kaidah-kaidah umum yang berlaku secara luas juga dengan mempertimbangkan kebiasaan-kebiasaan tradisional yang berlaku secara turun-temurun. Penduduk kedua desa ini memiliki rasa hormat yang tinggi kepada orang tua mereka, baik yang memiliki hubungan kekerabatan maupun yang tidak. Karena rasa hormat yang tinggi kepada orang tua itulah maka penduduk desa menggunakan sapaan khusus jika hendak menyapa orang yang lebih tua atau orang yang dianggap patut dihormati. Namun, ada suatu kebiasaan yang sudah ada sejak dahulu yaitu dengan menyapa anggota masyarakat tertentu dengan nama baru, yaitu nama julukan (oleh masyarakat disebut nama srani) selain nama dirinya sebagai cara untuk memberikan identitas tertentu kepada anggota masyarakat tersebut. Pemberian julukan ini bukan berarti penduduk desa tidak menghormati orang tersebut namun secara umum hal ini dimaksudkan untuk menunjukkan tingkat keakraban antara satu anggota masyarakat dengan anggota masyarakat yang lain.

Kebiasaan menyapa dengan julukan ini tidak serta-merta muncul dan diberikan begitu saja tanpa alasan khusus. Tentu saja ada sejumlah pertimbangan yang digunakan oleh masyarakat ketika menyapa seseorang dengan julukan. Julukan yang diberikan oleh masyarakat itu didasarkan pada sejumlah pertimbangan dan alasan khusus yang oleh masyarakat dianggap dapat menjadi identitas baru seseorang sehingga nantinya dikemudian hari masyarakat tidak lagi menggunakan nama diri seseorang untuk mengidentifikasi orang tersebut namun menggunakan julukan yang diberikan masyarakat kepadanya.

Dalam menyapa seseorang dengan nama julukan, masyarakat desa RumoongLansot menggunakan beberapa alasan khusus sebagai landasan penggunaan julukan 
tersebut. Alasan itu mencakup sejumlah pertimbangan seperti dengan memperhatikan kondisi fisik seseorang misalnya kelebihan atau kekurangan tubuhnya, nama-nama yang berhubungan dengan orang tertentu, kebiasaan yang sering dilakukan, tempat tinggal dan daerah asal, pangkat dan pekerjaan, peristiwa tertentu yang pernah dialami, dan beberapa hal lain yang menjadi ciri khas spesifik seseorang sehingga dia dianggap tepat untuk diberikan suatu julukan tertentu.

Penggunaan julukan kepada orang tertentu dalam masyarakat desa RumoongLansot biasanya dimulai dari hal-hal yang sangat sederhana namun kemudian menjadi awal yang baru dari kehidupan seseorang karena telah menyandang julukan baru di tengah masyarakat. Peristiwa-peristiwa yang biasanya memicu masyarakat hingga pada akhirnya menyapa seseorang dengan julukan baru sering kali terjadi tanpa sengaja baik saat sedang berkomunikasi dengan hanya satu orang maupun saat sedang berkomunikasi dengan banyak orang di tengah masyarakat. Penggunaan julukan baru tersebut dapat pula terjadi dalam situasi formal dan informal. Beberapa julukan yang sering diberikan kepada seseorang dan muncul pertama kali dalam situasi formal biasanya terjadi dalam situasi belajar di sekolah, khususnya ketika proses belajar membaca di dalam kelas. Kesalahan seseorang dalam membaca sebuah kata menyebabkan orang itu kemudian disapa dengan julukan baru sesuai kesalahan membaca yang dia lakukan. Sementara itu, situasi percakapan informal merupakan sumber utama penggunaan julukan baru kepada seseorang, seperti situasi percakapan di pasar, rumah makan, alun-alun desa, kerja bhakti, lapangan bola, kebun, nonton televisi bersama (antara tahun 1970-an hingga 1980-an) dan dalam percakapan masyarakat di petang hari setelah pulang dari kebun atau tempat kerja lainnya.

\section{A. Rumusan Masalah}

1. Apa saja bentuk dan makna sapaan julukan yang digunakan masyarakat RumoongLansot?

2. Apa saja jenis dan fungsi sapaan julukan yang diberikan oleh masyarakat? 


\section{Tujuan Penelitian}

1. Mengidentifikasi dan mengklasifikasi bentuk-bentuk julukan yang digunakan masyarakat

2. Mengidentifikasi dan Mendeskripsikan makna julukan yang digunakan masyarakat

\section{Metodologi Penelitian}

Penelitian ini bersifat deskriptif kualitatif karena menggunakan metode yang semata-mata hanya berdasarkan fakta yang ada dengan kajian yang tidak menggunakan prosedur-prosedur statistik. Data primer dalam penelitian ini diambil dari hasil wawancara dengan 20 (dua puluh) orang informan yang merupakan penduduk desa Rumoong-Lansot yang lahir dan bertumbuh hingga mencapai usia dewasa di desa Rumoong-Lansot. Usia mereka berkisar antara 12 hingga 80 tahun agar dapat mewakili masyarakat desa Rumoong-Lansot dari segi struktur usia. Selanjutnya data sekunder dikumpulkan lewat observasi lapangan dengan mengunjungi titik-titik keramaian desa seperti pasar, kantin, balai desa, dll, dengan mencatat percakapan antar warga desa yang berisi kata-kata julukan. Hal-hal yang dijadikan data dalam penelitian ini, baik primer maupun sekunder, ialah semua nama julukan yang digunakan oleh masyarakat desa Rumoong-Lansot guna mengidentifikasi makna leksikal dan latar belakang penggunaannya.

Penelitian ini dilakukan di desa Rumoong Atas dan Desa Lansot (selanjutnya disebut desa Rumoong-Lansot) yang masuk dalam wilayah kecamatan Tareran kabupaten Minahasa Selatan dalam wilayah penutur bahasa daerah Tontemboan. Secara geografis kedua desa ini terletak di jantung tanah Minahasa tepatnya diantara 2 (dua) gunung yang sangat terkenal yaitu Lokon dan Soputan. Jarak antara kota Manado dengan kedua desa ini yaitu sekitar $55 \mathrm{~km}$ dengan waktu tempuh perjalanan darat sekitar 90 menit. Jumlah penduduk di kedua desa ini ialah \pm 2.000 jiwa untuk desa Rumoong Atas dan \pm 1.250 jiwa untuk desa Lansot. Alasan peneliti memilih kedua desa ini sebagai obyek penelitian ialah karena peneliti menemukan adanya penggunaan nama 
julukan oleh penduduk desa dengan jumlah yang cukup tinggi dalam percakapan mereka sehari-hari.

Teknik analisis data dalam penelitian ini menggunakan langkah-langkah yang dikemukakan oleh Burhan Bungin (2003:70), yaitu: Pengumpulan Data, Reduksi Data, Display Data, Penegasan Kesimpulan dan Verifikasi. Untuk menganalisis bentukbentuk julukan, peneliti menggunakan teori yang dikemukakan oleh O'Grady dan Debrovolsky (1992:1) tentang pembagian cabang-cabang linguistik. Untuk menganalisis makna dan latarbelakangnya peneliti menggunakan teori Robins dalam Djajanegara (1992:30) yang menyatakan bahwa nama sebagai satuan lingual memiliki makna sosial dan historis. Untuk mengidentifikasi bentuk dan makna julukan yang bersifat asosiatif dan konotatif peneliti menggunakan teori yang dikemukakan oleh Hickerson (1980:131) dalam bukunya yang berjudul Linguistics Anthropology dan untuk mengidentifikasi jenis dan makna julukan yang berbentuk tabu peneliti menggunakan teori yang dikemukakan oleh Frazer (1955) yang membagi tabu menjadi

\section{E. Pembahasan}

Penggunaan julukan dalam komunikasi sehari-hari masyarakat desa RumoongLansot merupakan sebuah fenomena sosial karena sudah mendarah-daging dan telah menjadi bagian hidup masyarakat sejak waktu yang cukup lama. Dengan 280 jenis julukan yang dapat diidentifikasi oleh peneliti menunjukkan bahwa tingkat penggunaan julukan oleh warga desa sangatlah tinggi. Dikatakan bahwa penggunaan julukan ini sudah berlangsung sejak waktu yang cukup karena ditemukannya julukan-julukan kepada warga desa yang saat ini sudah meninggal yang jika mereka masih hidup usianya sudah sekitar 100 tahun, misalnya:

$\begin{array}{ll}\text { Servius Pasiowan } & \text { : Tete Isye Benggala } \\ \text { Nyonky Karundeng } & : \text { Lanos } \\ \text { Jan Peter Timbuleng } & : \text { Polet } \\ \text { Hein Kumaat } & : \text { Letnan }\end{array}$

Berdasarkan bentuknya, berbagai julukan yang digunakan masyarakat desa 
Rumoong-Lansot mampu mencakup hampir semua unsur linguistik yang ada baik aspek internal maupun eksternal sebagaimana yang dikemukakan dalam teori tentang pembagian cabang linguistik oleh O’Grady dan Debrovolsky, 1992:1. Bentuk-bentuk julukan yang masuk dalam aspek linguistik internal terbagi menjadi:

\section{a. Nomina}

\begin{tabular}{|c|l|l|l|}
\hline No & Bentuk Nomina & \multicolumn{1}{|c|}{ Makna } & Nama Diri \\
\hline 1 & dogol & $\begin{array}{l}\text { Nama peramal angka judi di era } \\
\text { tahun 1970an yang dijadikan } \\
\text { patokan memilih nomor }\end{array}$ & Alex Wurangian \\
\hline 2 & tede & Intonasi suara tidak stabil & Nona Tamboto \\
\hline
\end{tabular}

b. Verba

\begin{tabular}{|l|l|l|l|}
\hline No & Bentuk Verba & \multicolumn{1}{|c|}{ Makna } & \multicolumn{1}{|c|}{ Nama Diri } \\
\hline 1 & letok & Meledak, meletus & Hesty Kondoj \\
\hline 2 & tiba & Sampai, pulang, datang & Bobby Kalangi \\
\hline
\end{tabular}

c. Ajektiva

\begin{tabular}{|l|l|l|l|}
\hline No & Bentuk Ajektiva & Makna & Nama Diri \\
\hline 1 & sewe & Mulutnya miring, tidak simetris & NT \\
\hline 2 & sengit & Bau busuk yang menyengat/tajam & ML \\
\hline
\end{tabular}

d. Adverbia

\begin{tabular}{|c|c|c|c|}
\hline No & Bentuk Adverbia & Makna & Nama Diri \\
\hline 1 & surabaya & $\begin{array}{l}\text { Nama salah satu kota di pulau } \\
\text { Jawa yang merupakan Ibu Kota } \\
\text { Propinsi Jawa Timur }\end{array}$ & Itong Prang \\
\hline
\end{tabular}

e. Pronomina

\begin{tabular}{|l|l|l|l|}
\hline No & Bentuk & Makna & Nama Diri \\
\hline 1 & (d)aku & $\begin{array}{l}\text { Seorang laki-laki yang dalam } \\
\text { berbicara akan mengganti nama } \\
\text { dirinya dengan (d)aku }\end{array}$ & Joce Mokalu \\
\hline 2 & Ale & $\begin{array}{l}\text { Seorang laki-laki yang leluhurnya } \\
\text { dari Ambon yang dijuluki dengan }\end{array}$ & $\begin{array}{l}\text { Meson } \\
\text { Mamarimbing }\end{array}$ \\
\hline
\end{tabular}




\begin{tabular}{|l|l|l|l|}
\hline & $\begin{array}{l}\text { kata ganti orang kedua dalam } \\
\text { Bahasa Melayu Ambon }\end{array}$ & \\
\hline
\end{tabular}

f. Frase Nomina

\begin{tabular}{|l|l|l|l|}
\hline No & Frase Nomina & Makna & Nama Diri \\
\hline 1 & nyong der & $\begin{array}{l}\text { Seorang laki-laki yang tugasnya ialah } \\
\text { mengumpulkan derma saat ibadah } \\
\text { (der }=\text { derma) }\end{array}$ & Manuel Rumangu \\
\hline 2 & bang tunan & $\begin{array}{l}\text { Seorang laki-laki yang rumahnya } \\
\text { terletak di dekat sungai bernama } \\
\text { Tunan }\end{array}$ & Bang Lopaty \\
\hline
\end{tabular}

g. Frase Verba

\begin{tabular}{|l|l|l|l|}
\hline No & Frase Verba & Makna & Nama Diri \\
\hline 1 & deni demon & $\begin{array}{l}\text { Seorang laki-laki yang suka } \\
\text { mempertunjukkan keahliannya }\end{array}$ & Denny Sumayow \\
\hline 2 & edypepa & $\begin{array}{l}\text { Seorang laki-laki yang suka } \\
\text { berbohong }\end{array}$ & Eddy Kowel \\
\hline
\end{tabular}

h. Frase Ajektiva

\begin{tabular}{|l|l|l|l|}
\hline No & Frase Ajektiva & Makna & Nama Diri \\
\hline 1 & joni itam & $\begin{array}{l}\text { Seorang laki-laki yang selalu } \\
\text { mengatakan (h)itam kepada orang } \\
\text { yang dianggapnya bodoh }\end{array}$ & Johnny Kowel \\
\hline 2 & buang bengis & $\begin{array}{l}\text { Seorang perempuan yang } \\
\text { memiliki kulit berwarna gelap }\end{array}$ & Norma Kowel \\
\hline
\end{tabular}

i. Frase Adverbia

\begin{tabular}{|l|c|l|l|}
\hline No & Frase Adverbia & Makna & Nama Diri \\
\hline 1 & tete isye & Seorang laki-laki tua yang & Servius Pasiowan \\
& benggala & $\begin{array}{l}\text { memiliki badan yang besar seperti } \\
\text { orang dari India/Benggala }\end{array}$ & \\
& & & \\
\hline
\end{tabular}

\section{j. Ellipsis}




\begin{tabular}{|l|l|l|l|}
\hline No & Kalimat Elipsis & Makna & Nama Diri \\
\hline 1 & paham? & Seorang laki-laki yang setiap kali & Yantje Rorong \\
& & mengakhiri pembicaraannya akan & \\
& & bertanya 'paham?' yang & \\
& & sebenarnya berarti “apakah anda & \\
& & sudah mengerti maksud saya? & \\
\hline
\end{tabular}

\section{k. Konjungsi}

\begin{tabular}{|l|l|l|l|}
\hline No & Partikel & Makna & Nama Diri \\
\hline 1 & karna(lah) & $\begin{array}{l}\text { Seorang laki-laki yang selalu } \\
\text { menggunakan partikel 'karena' } \\
\text { dalam bentuk 'karna(lah)' saat } \\
\text { akan menghubungkan suatu } \\
\text { pembicaraan yang memiliki } \\
\text { hubungan sebab-akibat }\end{array}$ & \\
\hline 2 & yang & $\begin{array}{l}\text { Seorang laki-laki yang ayahnya } \\
\text { bernama Yang }\end{array}$ & Jus Kumaat \\
\hline
\end{tabular}

Julukan berbentuk ajektiva ditemukan sebagai julukan dengan jumlah terbanyak yaitu 13 (tiga belas) jenis, bentuk verba dan frase nomina berada pada urutan berikut dengan jumlah masing-masing 7 (tujuah) jenis. Bentuk nomina berjumlah 6 (enam) jenis, bentuk pronomina dan konjungsi 2 jenis, bentuk adverbia, frase adverbia dan kalimat ellipsis masing-masing 1 jenis.

Bentuk-bentuk julukan yang masuk dalam aspek eksternal linguistik terbagi menjadi :

\section{a. Gelar atau Pangkat}

\begin{tabular}{|l|l|l|l|}
\hline No & Gelar/Pangkat & Makna & Nama Diri \\
\hline 1 & kapala bepang & $\begin{array}{l}\text { Seorang laki-laki yang suka } \\
\text { mengkonsumsi kue bepang dan } \\
\text { pernah } \\
\text { pertandingan makan kue bepang. }\end{array}$ & Jantje Liud \\
\hline 2 & letnan & $\begin{array}{l}\text { Seorang laki-laki yang sudah } \\
\text { pensiun dari TNI dengan pangkat } \\
\text { terakhir Letnan }\end{array}$ & Hein Kumaat \\
\hline
\end{tabular}




\section{b. Istilah Kekerabatan}

\begin{tabular}{|l|l|l|l|}
\hline No & $\begin{array}{l}\text { Istilah } \\
\text { Kekerabatan }\end{array}$ & Makna & Nama Diri \\
\hline 1 & Om & $\begin{array}{l}\text { Seorang laki-laki yang } \\
\text { mewajibkan anak-anak untuk } \\
\text { menyapa dia dengan 'om' ketika } \\
\text { dia menjadi asisten sopir }\end{array}$ & Fery Kumaat \\
\hline 2 & paitua & $\begin{array}{l}\text { Seorang laki-laki yang karena satu } \\
\text { dan lain hal baru menikah saat } \\
\text { usianya sudah diatas 40 tahun }\end{array}$ & Jan Karundeng \\
\hline
\end{tabular}

c. Singkatan dan Akronim

\begin{tabular}{|l|l|l|l|}
\hline No & $\begin{array}{l}\text { Singkatan dan } \\
\text { Akronim }\end{array}$ & Makna & Nama Diri \\
\hline 1 & Dkt & $\begin{array}{l}\text { Seorang laki-laki yang berprofesi } \\
\text { sebagai tenaga medis di desa yang } \\
\text { semasa aktifnya di TNI bekerja } \\
\text { sebagai salah satu anggota Dewan } \\
\text { Kesehatan Tentara (DKT). }\end{array}$ & Jandoj \\
\hline 2 & Iput & $\begin{array}{l}\text { Seorang laki-laki yang dalam } \\
\text { berbicara dan bekerja dianggap suka } \\
\text { menipu (Iding Penipu) }\end{array}$ & Freddy Lapian \\
\hline
\end{tabular}

d. Istilah Tabu

\begin{tabular}{|l|l|l|l|}
\hline No & Bersifat Tabu & Makna Nama Diri & Narian \\
\hline 1 & dobol jarum & $\begin{array}{l}\text { Seorang laki-laki yang berprofesi } \\
\text { sebagai petugas medis lepas yang } \\
\text { diduga pernah melakukan } \\
\text { tindakan asusila }\end{array}$ & NK \\
\hline 2 & wem pki & $\begin{array}{l}\text { Seorang laki-laki yang terlibat } \\
\text { gerakan PKI pada masa lalu }\end{array}$ & WK \\
\hline
\end{tabular}

\section{e. Pelesetan Nama Diri}

\begin{tabular}{|l|l|l|l|}
\hline No & Pelesetan Nama & Makna & Nama Diri \\
\hline
\end{tabular}




\begin{tabular}{|l|l|l|l|}
\hline & Diri & & \\
\hline 1 & Uyer & Jeremia & Jeremia Slat \\
\hline 2 & bebek & $\begin{array}{l}\text { Nama tokoh kartun utama dalam } \\
\text { film Donald Duck / Donald Bebek }\end{array}$ & Donald Kowel \\
\hline
\end{tabular}

f. Nama Istri/Suami

\begin{tabular}{|l|l|l|l|}
\hline No & $\begin{array}{l}\text { Nama } \\
\text { Istri/Suami }\end{array}$ & \multicolumn{1}{|c|}{ Makna } & Nama Diri \\
\hline 1 & empeng & $\begin{array}{l}\text { Edy Prang yang istrinyabernama } \\
\text { Empeng }\end{array}$ & Edy Prang \\
\hline 2 & lance & $\begin{array}{l}\text { Edy Prang yang istrinya bernama } \\
\text { Lance }\end{array}$ & Edy Prang \\
\hline
\end{tabular}

g. Nama Orang Tua/Mertua

\begin{tabular}{|l|l|l|l|}
\hline No & Nama Orang Tua & \multicolumn{1}{|c|}{ Makna } & Nama Diri \\
\hline 1 & oke naning & $\begin{array}{l}\text { Seorang laki-laki yang ayahnya } \\
\text { bernama Naning }\end{array}$ & Royke Prang \\
\hline 2 & ai prit & $\begin{array}{l}\text { Seorang laki-laki yang ayahnya } \\
\text { bernama Prit }\end{array}$ & Askari Kumaat \\
\hline
\end{tabular}

h. Julukan dari Julukan Orang Tua

\begin{tabular}{|l|l|l|l|}
\hline No & $\begin{array}{c}\text { Julukan Orang } \\
\text { Tua/Mertua }\end{array}$ & \multicolumn{1}{|c|}{ Makna } & Nama Diri \\
\hline 1 & sjane dkt & $\begin{array}{l}\text { Seorang laki-laki yang ayahnya } \\
\text { dijuluki DKT }\end{array}$ & Sjane Kondoj \\
\hline 2 & rein gogos & $\begin{array}{l}\text { Seorang laki-laki yang ayahnya } \\
\text { dijuluki Gogos }\end{array}$ & Rein Kondoj \\
\hline
\end{tabular}

i. Julukan dari Julukan Kakek

\begin{tabular}{|l|l|l|c|}
\hline No & Julukan Kakek & \multicolumn{1}{|c|}{ Makna } & Nama Diri \\
\hline 1 & frandy jidon & $\begin{array}{l}\text { Seorang laki-laki yang kakeknya } \\
\text { dijuluki Jidon }\end{array}$ & Frandy Rorong \\
\hline
\end{tabular}




\begin{tabular}{|l|l|l|l|}
\hline 2 & nova sius & $\begin{array}{l}\text { Seorang laki-laki yang kakeknya } \\
\text { dijuluki Sius }\end{array}$ & Nova Sumendap \\
\hline
\end{tabular}

j. Nama Orang Lain

\begin{tabular}{|l|l|l|l|}
\hline No & Nama Orang Lain & \multicolumn{1}{|c|}{ Makna } & Nama Diri \\
\hline 1 & Gosal & $\begin{array}{l}\text { Seorang laki-laki yang pernah } \\
\text { tinggal bersama keluarga Gosal }\end{array}$ & Johnny Tamboto \\
\hline 2 & Pae & $\begin{array}{l}\text { Seorang laki-laki yang pernah } \\
\text { bekerja sebagai jurubayar } \\
\text { majikannya yang dijuluki Pae } \\
\text { waktu melakukan transaksi } \\
\text { cengkih Frang }\end{array}$ & \\
\hline
\end{tabular}

\section{k. Kesalahan Membaca}

\begin{tabular}{|l|l|l|l|}
\hline No & $\begin{array}{l}\text { Kesalahan } \\
\text { Membaca }\end{array}$ & Mama Diri \\
\hline 1 & Ibe & $\begin{array}{l}\text { Seorang laki-laki yang salah } \\
\text { membaca kata Ibu }\end{array}$ & Yoni Karwur \\
\hline 2 & Table & $\begin{array}{l}\text { Seorang laki-laki yang salah } \\
\text { membaca kata table (bah Inggris) }\end{array}$ & Nyong Tamboto \\
\hline
\end{tabular}

\section{Kesalahan Pelafalan}

\begin{tabular}{|l|l|l|l|}
\hline No & $\begin{array}{l}\text { Kesalahan } \\
\text { Pelafalan }\end{array}$ & Mama Diri \\
\hline 1 & Epe & $\begin{array}{l}\text { Seorang laki-laki yang salah } \\
\text { menyebut kata lepe (lemah) }\end{array}$ & Fentje Kumaat \\
\hline 2 & Leto & $\begin{array}{l}\text { Seorang perempuan yang salah } \\
\text { menyebut kata lewo (jahat) }\end{array}$ & Rosye Slat \\
\hline
\end{tabular}

m. Abnormalitas Fisik/Psikis

\begin{tabular}{|c|c|c|c|}
\hline No & $\begin{array}{c}\text { Abnormalitas } \\
\text { Fisik/Psikis }\end{array}$ & Makna & Nama Diri \\
\hline
\end{tabular}




\begin{tabular}{|l|l|l|l|}
\hline 1 & ai lampeng & $\begin{array}{l}\text { Seorang laki-laki yang ada kutil } \\
\text { dekat telinganya }\end{array}$ & Adrin Kumaat \\
\hline 2 & tomy kribo & $\begin{array}{l}\text { Seorang laki-laki yang } \\
\text { rambutnya keriting }\end{array}$ & Tomy Kawatu \\
\hline
\end{tabular}

n. Nama Tokoh Terkenal/Karater Film

\begin{tabular}{|l|l|l|l|}
\hline No & $\begin{array}{l}\text { Tokoh Terkenal / } \\
\text { Karakter Film }\end{array}$ & \multicolumn{1}{|c|}{ Makna } & Nama Diri \\
\hline 1 & Able & $\begin{array}{l}\text { Seorang laki-laki yang mirip } \\
\text { dengan pemeran pak Able salah } \\
\text { satu penjaga Pos Kamling dalam } \\
\text { serial kartun Si Unyil }\end{array}$ & Yanny Liud \\
\hline 2 & Butet & $\begin{array}{l}\text { Seorang laki-laki yang mirip } \\
\text { dengan karakter Butet dalam } \\
\text { sebuah film perjuangan karena } \\
\text { adanya kesamaan berupa luka di } \\
\text { dekat telinga mereka }\end{array}$ & \\
\hline
\end{tabular}

o. Behubungan dengan Suku Bangsa Lain

\begin{tabular}{|l|l|l|l|}
\hline No & Suku Bangsa Lain & \multicolumn{1}{|c|}{ Makna } & Nama Diri \\
\hline 1 & Batak & $\begin{array}{l}\text { Seorang laki-laki yang dijuluki } \\
\text { dengan nama salah satu suku dari } \\
\text { pulau Sumatera dengan pola } \\
\text { yang mengikuti nama dirinya }\end{array}$ & Yantje Slat \\
\hline 2 & ambong & $\begin{array}{l}\text { Seorang laki-laki yang dijuluki } \\
\text { dengan nama salah satu suku dari } \\
\text { Propinsi Maluku karena } \\
\text { rambutnya mirip dengan } \\
\text { penduduk asli suku tersebut }\end{array}$ & \\
\hline
\end{tabular}


p. Nama Makanan/Produk Lain

\begin{tabular}{|l|l|l|l|}
\hline No & $\begin{array}{l}\text { Makanan / Produk } \\
\text { Lain }\end{array}$ & \multicolumn{1}{|c|}{ Makna } & Nama Diri \\
\hline 1 & kapstan & $\begin{array}{l}\text { Seorang laki-laki yang suka } \\
\text { sekali dengan salah satu merek } \\
\text { rokok tertentu yang kemudian } \\
\text { menjadi julukannya }\end{array}$ & Joce Karundeng \\
\hline 2 & Pia & $\begin{array}{l}\text { Seorang laki-laki yang pekerjaan } \\
\text { ibunya ialah sebagai pembuat } \\
\text { kue pia }\end{array}$ & Jantje Prang \\
\hline
\end{tabular}

q. Nama Jenis Olahraga

\begin{tabular}{|l|l|l|l|}
\hline No & Jenis Olahraga & \multicolumn{1}{|c|}{ Makna } & Nama Diri \\
\hline 1 & karate & $\begin{array}{l}\text { Seorang laki-laki yang ketika } \\
\text { berbicara selalu menirukan } \\
\text { gerakan-gerakan mirip karate } \\
\text { untuk mendukung maksud } \\
\text { pembicaraannya }\end{array}$ & Alek Weol \\
\hline 2 & tangkawek & $\begin{array}{l}\text { Seorang laki-laki yang dianggap } \\
\text { menguasai jenis olahraga beladiri } \\
\text { yang memaksimalkan kekuatan } \\
\text { jari tangan }\end{array}$ & Johnny Kumaat \\
\hline
\end{tabular}

r. Peristiwa Alam

\begin{tabular}{|l|l|l|l|}
\hline No & Peristiwa Alam & \multicolumn{1}{|c|}{ Makna } & Nama Diri \\
\hline 1 & Petir & $\begin{array}{l}\text { Seorang laki-laki yang pernah } \\
\text { disambar petir dalam perjalanan } \\
\text { pulang dari kebunnya }\end{array}$ & Nyong Rorong \\
\hline
\end{tabular}


s. Berhubungan dengan Istilah Medis

\begin{tabular}{|c|c|c|c|}
\hline No & Istilah Medis & Makna & Nama Diri \\
\hline 1 & Saraf & $\begin{array}{l}\text { Seorang laki-laki yang ketika } \\
\text { berbicara terkesan kurang } \\
\text { mempertimbangkan akal sehat } \\
\text { walaupun dia tidak mengalami } \\
\text { gangguan jiwa sedikitpun }\end{array}$ & \\
\hline 2 & Kudis & $\begin{array}{lrr}\text { Seorang perempuan } & \text { yang } \\
\text { menderita penyakit kulit } & \end{array}$ & \\
\hline
\end{tabular}

Robins dalam Djajanegara (1992:30), menyatakan bahwa nama sebagai satuan lingual memiliki makna sosial dan historis."Verbalisasi bukan semata-mata memberi nama secara pasif kepada obyek-obyek tertentu. Kelestarian nama-nama mewajibkan kita untuk mengenal identitas yang nyata dalam arus gejala yang diamati secara terusmenerus". Dengan mengacu pada prinsip ini dan dengan mempertimbangkan teori penamaan oleh Helena and Laird maka peneliti telah mengelompokkan julukan-julukan kedalam 7 (tujuh) kategori umum yang diklasifikasikan berdasarkan latar belakang sosial dan historisnya sehingga setiap julukan memiliki makna sosial dan historis. Ketuju kategori tersebut ialah:

\section{Kondisi Fisik}

Kondisi fisik dijadikan pertimbangan utama masyarakat dalam memberikan julukan karena aspek inilah yang pertama kali terlihat dan mudah diidentifikasi ketika kita membicarakan tentang seseorang. Jika terdapat kesamaan pada kondisi fisik seseorang maka masyarakat akan menggunakan julukan yang berbeda dengan makna yang sama kepada referen bebeda. Contoh yang paling menonjol untuk kasus ini ialah adanya beberapa referen dengan kondisi fisik yang dianggap pendek dan mendapatkan julukan yang berbeda-beda namun memiliki makna yang sama. Sebagai contoh:

Rocky Mokalu / Daud

Julien Kumaat / Ulin Potot

$$
\text { : Julukan }+\Theta
$$

: FN + Julukan 


$\begin{array}{ll}\text { Denny Kumaat / Denny Petol } & \text { : FN + Julukan } \\ \text { Maxi Sendow / Pekos } & : \text { Julukan }+\Theta \\ \text { Jenry Senewe / Petot } & : \text { Julukan }+\Theta \\ \text { Jan Lumempouw / Botet } & \text { : Julukan }+\Theta \\ \text { Nona Tampie / Ekek } & \text { : Julukan }+\Theta\end{array}$

Ketujuh referen di atas merupakan warga dengan ukuran tubuh yang dianggap pendek dan mendapatkan julukan yang berbeda-beda.

Hal yang sama juga terjadi pada referen-referen dengan bentuk tubuh yang besar atau gemuk yang mendapatkan julukan yang berbeda-beda. Sebagai contoh:

$\begin{array}{ll}\text { Yantje Sumakul / Gem } & \text { : Julukan }+\Theta \\ \text { Marlyn Rumengan / Kambuna } & \text { : Julukan }+\Theta \\ \text { Jansye Rumengan / Atut } & \text { : Julukan }+\Theta \\ \text { Maxi Tampie / Maxi Gode } & \text { : FN + Julukan } \\ \text { Nova Karamoy / Nova Salem } & \text { : FN + Julukan } \\ \text { Yansje Rumengan / Didu } & \text { : Julukan }+\Theta \\ \text { Ben Watung / Kentung } & \text { : Julukan }+\Theta \\ \text { Yul Karundeng / Ontet } & \text { : Julukan }+\Theta \\ \text { Olsje Prang / Bumba } & \text { : Julukan }+\Theta \\ \text { Jan Timbuleng / Polet } & \text { : Julukan }+\Theta\end{array}$

\section{Nama yang Berhubungan dengan Referen}

Julukan yang berhubungan dengan nama tertentu ditemukan dalam jumlah yang besar di desa Rumoong-Lansot. Diketahui ada 79 julukan yang terkait dengan nama yang mencakup pelesetan nama diri, nama suami/istri, nama dan julukan orang tua/mertua/kakek, serta nama-nama lainnya. Julukan dari pelesetan nama diri berada 
pada posisi teratas dari segi jumlah penggunaannya karena masyarakat menganggap bahwa dengan memelesetkan nama diri seseorang akan lebih mudah untuk diidentifikasi, sebagai contoh:

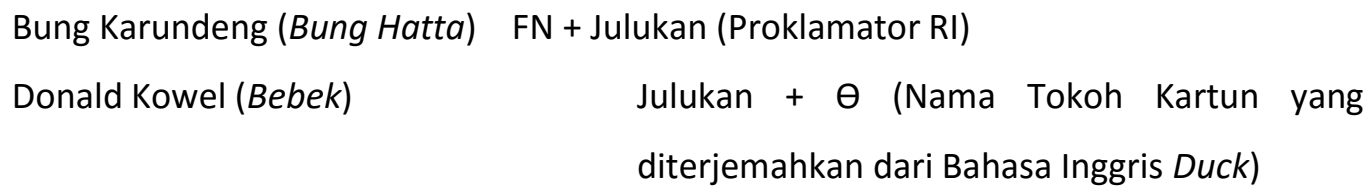

Dalam hal pemelesetan nama, peneliti menemukan bahwa ada 2 (dua) kasus menarik ketika satu julukan yang diberikan oleh masyarakat kepada referen tertentu diberikan juga kepada anaknya bahkan kepada cucunya. Kasus pertama yaitu Gideon Rorong yang dijuluki Jidon, kemudian anaknya yang bernama Anne Rorong menjadi Anne Jidon dan selanjutnya kepada cucunya yang bernama Frandy Rorong menjadi Frandy Jidon. Kasus kedua yang agak berbeda yaitu ketika seseorang dengan nama diri Alvius Sumendap oleh masyarakat diberikan julukan Sius. Namun, julukan ini tidak menjadi julukan anaknya (Joce Sumendap) tetapi justru dijadikan julukan kepada cucunya yaitu Nova Sumendap menjadi Nova Sius.

\section{Kebiasaan}

Kebiasan seseorang tidak luput dari pengamatan masyarakat untuk menjadikannya sebagai julukan. Biasanya, kebiasaan yang dijadikan julukan ialah sesuatu yang telah dilakukan sebanyak beberapa kali dalam kurun waktu yang relatif lama, seperti:

$\begin{array}{ll}\text { Tiba }(\text { Julukan }+\Theta) & \text { Diberikan kepada Bobby Kalangi yang } \\ \text { biasanya pergi meninggalkan desa dan dalam waktu } \\ \text { yang tidak lama kembali lagi. }\end{array}$


ProNomina (D)aku sebagai pengganti nama dirinya.

Namun, ada pula kebiasaan yang baru beberapa kali dilakukan dalam waktu yang tidak lama tetapi sudah dijadikan julukan, yaitu:

Non Kalaper (FN + Julukan)

Lekok (Julukan $+\theta)$
Diberikan kepada Non Marentek karena lari meninggalkan rumah ketika ada tamu yang mengunjungi dia di rumahnya. Peristiwa ini baru terjadi sebanyak 2 (dua) kali namun referen sudah mendapatkan julukan tersebut. Diberikan kepada William Runkat karena suka mengamuk dan ganas ketika ada keinginannya yang tidak terpenuhi. Peristiwa mengamuknya referen baru beberapa kali terjadi namun dia sudah mendapatkan julukan itu.

\section{Tempat Tinggal dan Daerah Asal}

Salah satu julukan yang paling populer di desa Rumoong-Lansot ialah julukan yang berhubungan dengan keterangan tempat (Adverbia) yang diberikan kepada Itong Prang yaitu Surabaya $($ Adverbia $+\Theta)$. Dikatakan sangat populer karena tempat tinggal referen berada di depan pasar tradisional sebagai batas pemisah antara desa RumoongAtas dan Desa Lansot sehingga referen selalu berada di tengah pusat interaksi sosial masyarakat desa. Julukan ini diberikan kepada referen karena dia diduga menjadi orang pertama dari desa Rumoong-Lansot yang berlayar ke kota Surabaya. Walaupun diketahui kemudian ada sejumlah warga desa yang melakukan perjalanan ke Surabaya namun mereka tidak dijuluki Surabaya karena julukan tersebut sudah melekat kuat pada referen yang bernama Itong Prang.

Selain Surabaya, ada juga julukan lain yang digunakan untuk mengidentifikasi orang dengan menggunakan nama kota tertentu namun dengan popularitas yang agak rendah. Julukan tersebut ialan Ambon $(g)$. Julukan ini diberikan kepada Jemmy Slat yang leluhurnya diduga berasal dari Ambon dan kepada Tengku yang memang berasal dari Ambon. Hal menarik dengan julukan yang terkait dengan $\operatorname{Ambon}(g)$ ialah adanya seorang warga yang leluhurnya juga dari Ambon tetapi tidak serta-merta diberikan 
julukan Ambon(g), yaitu Meson Mamarimbing. Walaupun leluhurnya berasal dari Ambon namun julukan yang diberikan kepadanya ialah Ale, yaitu suatu bentuk ProNomina dalam Bahasa Melayu Ambon yang berarti Engkau.

\section{Gelar dan Pekerjaan}

Julukan yang berhubungan dengan jenis pekerjaan yang paling akrab di telinga warga desa Rumoong-Lansot ialah DKT. Julukan ini diberikan kepada Jan Kondoj yang merupakan seorang pensiunan TNI dan menjalankan profesi sebagai petugas kesehatan lepas di desa, khususnya dalam membantu persalinan warga kurang mampu di kedua desa ini. Pekerjaannya yang terkait langsung dengan masyarakat menyebabkan julukan $D K T$ sangat akrab di telinga warga. Karena populernya nama ini maka anak peremuannya yang bernama Sjane Kondoj akhirnya dijuluki Sjane DKT.

Salah satu julukan yang berhubungan dengan gelar yang diberikan kepada seorang referen dan yang bahkan mampu menggeser julukan yang sudah disandang sebelumnya ialah julukan Dewan yang diberikan kepada Hans Karundeng. Pada awalnya, Hans Karundeng mendapatkan julukan Lanos dari julukan ayahnya yaitu Nyongky Lanos. Setelah referen ini mendapatkan jabatan sebagai anggota DPRD Minahasa pada tahun 1980-an maka sejak saat itu dan hingga saat ini setelah dia lama melepaskan jabatan tersebut referen ini tetap dijuluki Dewan sebagai julukannya yang kedua.

\section{Peristiwa Tertentu}

Peristiwa tertentu yang terjadi dalam kehidupan seseorang dan kemudian oleh masyarakat desa dijadikan sebagai julukan biasanya merupakan peristiwa yang tidak dialami atau dilakukan orang lain. Julukan yang diberikan dalam kaitannya dengan peristiwa khusus ialah Dobol Jarum kepada NK dan Tempeyen kepada JK. Di satu sisi, julukan ini sebenarnya bersifat tabu karena mengandung makna yang buruk dan memalukan, namun di sisi lain masyarakat biasanya akan tertawa ketika mendengar julukan ini walaupun mereka sudah sering mendengarkannya karena kedua julukan tersebut mengantarkan pikiran masyarakat kembali pada masa lalu ketika terjadinya peristiwa spesifik terkait dengan kedua referennya. Dobol Jarum yang berarti dua jarum diberikan kepada referennya karena profesinya sebagai tenaga medis yang biasanya mengobati warga dengan cara menyuntikkan obat lewat jarum diduga melakukan tindak 
asusila dengan salah satu pasiennya. Bagian kisah ini yang sering membangkitkan rasa humor masyarakat terkait dengan profesi referen ini yang biasanya mengobati pasiennya dengan menyuntikkan obat melalui jarum suntik, namun ternyata dia juga menggunakan "jarumnya" yang lain untuk tujuan asusilanya. Sementara itu, julukan Tempeyen juga tidak kala humoris. Masyarakat biasanya tertawa ketika mendengar julukan ini karena diketahui bahwa referennya diduga pernah melakukan perselingkuhan dengan perempuan dari desa lain dan digrebek oleh warga desa lain tersebut. Saat digrebek, masyarakat kemudian meneriaki referen ini dengan sebuah kata spesifik yaitu tempeyen dalam bahasa Tontemboan yang berarti pelaku asusila.

\section{Asosiatif dan Konotatif}

Selain bentuk-bentuk julukan di atas, peneliti juga menemukan bahwa terdapat 16 bentuk julukan yang bersifat Asosiatif dan 5 bentuk julukan yang bersifat Konotatif sesuai dengan teori yang dikemukakan oleh Hickerson (1981: 131). Untuk aspek asosiatif, peneliti menemukan bahwa masyarakat desa Rumoong-Lansot suka menyandingkan individu tertentu dengan nama-nama binatang. Diketahui bahwa ada 5 (lima) jenis binatang yang dijadikan julukan kepada warga desa tertentu yaitu Gajah, Angsa, Cecak, Kus-Kus, dan Badak. Penggunaan julukan ini disebabkan karena referen yang dijuluki dianggap memiliki keserupaan spesifik dengan binatang-binatang tersebut baik dari segi fisik maupun kebiasaan. Khusus untuk gajah ditemukan ada 3 (tiga) warga yang diberikan julukan tersebut, yaitu: Agustinus Kumaat/Jus Gajah, Steven Konjoj/Gajah, dan Maxi Slat/Maxi Gajah. Julukan Gajah diberikan kepada Agustinus Kumaat dan Steven Konjoj karena ukuran tubuh mereka yang dianggap lebih besar daripada warga lain, walaupun bentuk julukannya berbeda, yaitu:

$$
\begin{array}{ll}
\text { Agustinus Kumaat (Jus Gajah) } & \text { : Julukan + Nama Binatang } \\
\text { Steven Kondoj (Gajah) } & \text { : Julukan }+\Theta
\end{array}
$$

Di lain pihak, julukan Gajah diberikan kepada Maxi Slat bukan karena badannya yang besar namun karena telinganya yang dianggap lebih besar daripada ukuran normal, dengan pola:

$$
\text { Maxi Slat (Maxi Gajah) } \quad \text { : FN + Julukan Binatang }
$$


Sementara itu julukan Angsa diberikan kepada Alo Kondoj karena kebiasaannya yang suka mengeluarkan bunyi serupa dengan suara bebek angsa, dengan pola:

Alo Kondoj (Tete Angsa) : Istilah Kekerabatan + Julukan Binatang

Jantje Prang mendapatkan julukan Cacak (Cecak) karena suka menirukan suara cecak secara akurat, dengan pola:

Jantje Prang $(\mathrm{Caca}) \quad$ : Julukan Binatang $+\Theta$

Punggungnya yang berbulu menyebabkan Hanny Liud diberikan julukan Kuse karena dianggap mirip dengan binatang Kus-Kus, dengan pola:

\section{Hanny Liud (Hanny Kuse) $\quad$ : FN + Julukan Binatang}

Keserupaan tingkah-laku menjadi pertimbangan warga untuk mengkonotasikan warga yang lain dengan orang atau obyek tertentu. Sebagai contoh, karena sifatnya yang pemarah maka Alek Slat dijuluki Saddam, nama kecil mantan presiden Irak Saddam Hussein yang kejam dan otoriter, dengan pola:

$$
\text { Alex Slat }(\text { Saddam }) \quad \text { : Julukan }+\Theta
$$

\section{Julukan Tabu}

Tabu merupakan suatu pelanggaran sosial yang kuat terhadap kata, benda, tindakan atau orang yang dianggap tidak diinginkan oleh suatu kelompok, budaya atau masyarakat. Tabu dapat juga membuat malu, aib, dan perlakuan kasar dari lingkungan sekitar. Frazer (1955) membagi tabu menjadi: tabu tindakan, tabu orang, tabu benda/hal, dan tabu kata-kata. Jenis tabu kata-kata selanjutnya dibagi lagi menjadi: tabu nama orang tua, tabu nama kerabat, tabu nama orang yang sudah meninggal, tabu nama binatang, tabu nama Tuhan, dan tabu kata-kata tertentu. Jenis julukan tabu merupakan julukan yang cukup akrab di telinga masyarakat karena referennya diduga pernah terlibat atau pernah melakukan sesuatu yang oleh masyarakat secara umum dianggap sebagai sesuatu yang buruk, sebagai contoh:

Wem PKI $\quad$ FN + Julukan Tabu $\rightarrow$ WK

\section{Faktor Lain.}

Masih ada begitu banyak alasan lain yang digunakan masyarakat untuk 
menjuluki seseorang agar orang tersebut selanjutnya diidentifikasi dengan julukannya itu. Beragamnya alasan lain ini kadang tidak dapat ditelusuri asal-muasalnya namun satu yang pasti ialah pemberian julukan kepada seseorang dimaksudkan untuk mengidentifikasi orang tersebut dengan sesuatu yang dianggap tepat untuk menggambarkan ciri khas yang paling menonjol pada orang tersebut. Contoh-contoh julukan populer di desa Rumoong-Lansot dengan alasan pemberiannya yang tidak pasti ialah:

Nyong Karundeng = Tokes
$\begin{array}{ll}\text { Jacob Rorong } & \text { Oding } \\ \text { Jus Oroh } & =\text { Totoi } \\ \text { Alfred Rumangu } & =\text { Ule }\end{array}$

Dari semua jenis julukan yang berhasil diperoleh di desa Rumoong-Lansot ditemukan bahwa julukan yang berhubungan dengan ketidaksempurnaan fisik dan psikis berada pada posisi teratas dengan jumlah 87 referen. Setelah ketidaksempurnaan fisik dan psikis, jenis julukan terbanyak berikut berhubungan dengan nama referen yaitu 78 jenis, kebiasaan 64 jenis, tempat tinggal dan daerah asal 12 jenis, pekerjaan 8 jenis, peristiwa tertentu 7 jenis, dan faktor lain 2 jenis.

\section{F. Kesimpulan}

Penggunaan julukan dalam komunikasi sehari-hari warga desa Rumoong-Lansot merupakan sebuah fenomena unik yang memiliki daya tarik khusus baik dari segi bahasa maupun sosial-budaya. Masyarakat desa merasa memiliki hubungan yang semakin akrab jika dalam komunikasi mereka digunakan julukan-julukan tertentu dalam menyapa satu dengan yang lainnya.

Berdasarkan tujuan penelitian yang telah ditetapkan, peneliti akhirnya dapat mengemukakan beberapa penjelasan berikut ini:

1. Julukan-julukan yang ada di desa Rumoong-Lansot memiliki bentuk yang mencakup hampir semua unsur linguistik yang ada dalam aspek linguistik internal dan aspek linguistik eksternal.

2. Masyarakat Rumoong-Lansot sudah menggunakan julukan sebagai salah satu cara untuk menciptakan dan memelihara keakraban antar sesama anggota masyarakat sejak waktu yang cukup lama. Julukan-julukan yang ada di desa Rumoong-Lansot muncul dari berbagai latar belakang yang berbeda-beda. 


\section{DAFTAR PUSTAKA}

Ervin-Tripp S,M. 1971. Sociolinguistics of Address. USA: The Hague Mount \&

Co.

Fishman, Joshua. 1971. Advance in the Sociology Language. Paris: The Hague Mount \& Co

Fitzpatrick, Liseli A, BA. 2012. African Names and Naming Practices: The Impact Slavery and European Domination Had on the African Psyche, Identity and Protests. Ohio: Ohio State University

Hakim, Noorviaty. 1991. Kata Sapaan Bahasa Ternate dan Bahasa Inggris. Manado: Fakultas Sastra UNSRAT

Hasdian. 2004. Analisis Kontrastif Kata Ganti Bahasa Inggris dan Bahasa Wolio (Buton). Manado: Fakultas Sastra UNSRAT

Ishak, Sandra D. 2001. Bentuk-Bentuk Sapaan dalam Drama The Glass Manageries Karya Tennessee Williams. Manado: Fakultas Sastra UNSRAT

Kalesaran, Eirene E.P. 2015. Nama Keluarga dalam Bahasa Inggris dan Bahasa Kaili: (Analisis Kontrastif). Manado: Fakultas IImu Budaya UNSRAT

Kridalaksana, Harimurti. 1993. Kamus Linguistik. Jakarta: Gramedia Kridalaksana, Harimurti. 1985. "Fungsi Bahasa dan Sikap Bahasa". Flores: Nusa Indah.

Kapantow, Kheren Y. 2008. Nama-Nama Panggilan dalam Bahasa Inggris dan Bahasa China: Suatu Analisis Kontrastif. Manado: Fakultas Sastra UNSRAT

Leko, Fredy. 1991. Analisis Kontrastif Kata Ganti Bahasa Inggris dan Bahasa Makassar. Manado: Fakultas Sastra UNSRAT

Lotulung, D.R. 1983. Sistem Sapaan Bahasa Melayu Manado di Kota Manado. Manado: Fakultas Sastra UNSRAT.

Lyons, John. 1977. Introduction to Theoretical Linguistics. London: Cambridge University Press

Mahsun. 2001. Penelitian Bahasa: Berbagai Tahapan Strategi, Metode, dan Tekniknya. Diterbit, Direktorat Jenderal Pendidikan Tinggi. Jakarta. 
Mandagi, C. Hanneke. 1992. Penggunaan Bentuk Sapaan Bahasa Inggris untuk MC. Manado: Fakultas Sastra UNSRAT.

Moleong, Lexy J. 2001. Metodologi Penelitian Kualitatif. Remaja Rosdakarya. Bandung. 2001 